\title{
PHILOLOGY
}

\section{COMPATIBILITY OF LANGUAGE UNITS IN THE KAZAKH LANGUAGE AND THEIR CAPABILITY}

\author{
Amirbekova Aigul Baydebekkyzy, candidate of philological sciences, \\ Head of the Lexicology Department \\ Khabiyeva Almagul, candidate of philological sciences \\ Soltanbekova Alfia, candidate of philological sciences \\ Taubaldiyev Meirambek, master of philological sciences
}

Institute of Linguistics named after A. Baitursynov, Kazakhstan

DOI: https://doi.org/10.31435/rsglobal_sr/30092019/6682

\section{ARTICLE INFO}

Received 18 July 2019

Accepted 13 September 2019

Published 30 September 2019

\section{KEYWORDS}

valency, compatibility, language, word semantics, syntagmatic, logical, lexical, grammatical relation.

\begin{abstract}
The article deals with the concept of valency as a phenomenon lying at the confluence of syntax and lexical semantics. The paper also represents types of valency, directions in which the theory of valency is considered. Valency in the broad sense of the word refers to the capacity of a language unit to enter into communication with other units of a particular order. Objectivity and scientific and practical significance of the theory of valency is determined by the lexicalsemantic potential of the word. Semantic valency is based on the logical semes of the word semantics. These semes are consistent with the logical semes of the another word meanings, as a result, the given word demonstrates the combining capability with another word. This is considered to be its semantic valency. We have attempted to identify and investigate a peculiar kind of valency in the Kazakh language. We use the concepts of valency and compatibility as synonyms, but in a number of works they are distinguished.
\end{abstract}

Citation: Amirbekova Aigul Baydebekkyzy, Khabiyeva Almagul, Soltanbekova Alfia, Taubaldiyev Meirambek. (2019) Compatibility of Language Units in the Kazakh Language and their Capability. Science Review. 7(24). doi: 10.31435/rsglobal_sr/30092019/6682

Copyright: (C) 2019 Amirbekova Aigul Baydebekkyzy, Khabiyeva Almagul, Soltanbekova Alfia, Taubaldiyev Meirambek. This is an open-access article distributed under the terms of the Creative Commons Attribution License (CC BY). The use, distribution or reproduction in other forums is permitted, provided the original author(s) or licensor are credited and that the original publication in this journal is cited, in accordance with accepted academic practice. No use, distribution or reproduction is permitted which does not comply with these terms.

1. Introduction. Compatibility is the main feature of language units based on syntagmatic relations. Syntagmatic relations is the capacity of language units to link to one another in a speech sequence as a part of the text, sentence, words in accordance with the laws of language. Compatibility is a linguistic category spread in every area of language. The rule that holds "combinability is the combination of words with words, sentence with sentence" is stereotypical and recognized only at the grammatical level. Sounds in the language have the capability to be combined or not to be combined with each other. Affixes are attached to the root differentially under the laws of language. Words are also combined with each other depending on the content plane and the expression plane. To the extent that this is true, the compatibility phenomenon is the category that plays a significant role in determining phonetic, lexical, morphological, syntactic laws of the language. In this paper, the concept of compatibility is considered equivalent to the concept of valency, since valency is a key indicator defining the capacity of all language units to be combined with each other from the language sounds to the texts onwards.

2. Methods. S. D. Katznelson, a scientist who recognized that a valency phenomenon occurs in all areas of linguistics and introduced the concept of valency into the language; in his research he wrote: "There are two types of valency in language: one is formal, the second is content-related. Formal valency is related to a certain word form and is determined by elements of synthetic morphology and the content side depends on the word meaning" [1, p.21]. Scientists investigated the concept of valency in language later, who say that the types of compatibility are not limited to it, 
distinguish several types. According to the German scientist G. Helbig: "There are three levels of valency in language: logical, semantic, syntactic. Here, the logical valency is considered as an extralinguistic level of compatibility between concepts, semantic valency - is a combination of semantic components (thing or objects of the phenomenon and their properties) in the word, as well as their capability to be combined according to their meaning. Syntactic valency - is the capability of individual words to be combined (free collocations, phraseological combinations and etc.) under mandatory and optional (additional) relations of individual words" [2, p.157].

The idea that the notion of compatibility known only at the grammatical level, which is reflected in structural linguistics, began to change. It is proved that the function of word compatibility within the meaning is the basis for the formation of phonosemantic, morphosemantic fields. In scholars' post surveys, sorts and types of compatibility only increased. According to V. Gak, "Grammatical word combination indicates its relation to a certain part of speech, and lexical compatibility is a choice and use of words in accordance with its meaning, semantic compatibility considers mutual semantic relationship of two components" [3, p.483].

Scientist N.Z. Kotelova defines "syntactic word compatibility as a complex and peculiarities of the potential words able to form syntactic relations; and lexical combinability as a complex and a condition for the realization of the phrases able to combine within the meaning, and distinguishes 2 types of compatibility: absolute compatibility and relative compatibility. Absolute compatibility is a compatibility that does not require words of interdependence of the components. Relative compatibility is a combination of significant concepts that interact directly with each other $[4, \mathrm{p} .8]$.

According to M. Vlavatsky: "Word valency is a potential of language syntagmatics and its consideration is required when creating all sorts of combinatorial dictionaries, which gives a systematic description of the syntagmatic relations (syntactic and/or lexical-semantic) most frequent words of a particular language [5, p.7]. I. M. Boguslavsky understands valency as a peculiarity of the word L to describe the situation in which there is a participant X... The word has as many valencies as the participants of the situation (semantic actants), it is necessary to mention in order to interpret it in a comprehensive and an irredundant way [6, p.360]. The current situation in the German theory of valency in the 60-70-ies of the XX century contributed to the emergence of two theoretical approaches, syntactic and semantic. Adherents of the first direction (G. Helbig, W. Flemig) considered valency as a phenomenon of the expression plane, pointed to the autonomy of the three levels of valency and their independence from each other in the description using different categories. The given concept is the basis of "Wörterbuch zur Valenz und Distribution deutscher Verben" which describes the syntactic valency of verbs. For example [7, p. 238]

Einsteigen I. einsteigen 1+(1) = 2 II. einsteigen $\rightarrow \mathrm{Sn},(\mathrm{pS})$ III. Sn $\rightarrow$ Hum (Der Fahrgast steigt ein) $\mathrm{P}=$ in, durch Wenn $\mathrm{p}=$ in $\mathrm{pSa} \rightarrow 1$. Dir (Er steigt in das Auto ein) 2. Abstr (Er steigt in das Geschaft ein) Wenn $\mathrm{p}=$ durch $\mathrm{pSa} \rightarrow$ Anim (Er steigt durch das Fenster ein) the Authors of the given dictionary (G. Helbig and V. Schenkel) understand valency as the most important means of describing a language and teaching a foreign language under the conditions when the subject is given a certain position which is differentiated by quite strict methods of construction between mandatory and optional actants. The actants are the subjects, objects, adverbial modifiers, and prepositional objects. Syntactic valency is a verb ability to open empty spaces around itself which can or should be occupied by obligatory and optional actants. Verb description is carried out in three stages: 1) setting the number of actants (valency); 2) setting the syntactic environment of verbs in strictly formal terms; 3) semantic environment of verbs. Authors understand valency as an identification of open semantic and syntactic positions, as well as their syntactic filling. The valence model is based on syntactic valency. Representatives of the second, the so-called semantic direction (V. Bondzio, K. E. Zommerfeldt, etc.), consider this concept as a phenomenon of the content plane believing that valency represents a manifestation of the lexical word meaning. Syntactic valency is considered as an expression form of logical-semantic relations and underlies in the valency dictionary description and distribution of German adjectives [8] and nouns where the description unit is a lexical-semantic variant. However, in their dictionaries, the adherents of the second direction demonstrate words in isolation and do not take into account the word connections with their partners. As a positive aspect of this theory, it should be noted that valency is considered not only in quantitative terms, but also in morphological and semantic terms, and the syntactic function of the adjective in the sentence is taken into account as well [8].

In Kazakh linguistics before the emergence of the valency theory grammatical compatibility was determined due to the forms of word communication.

M. Balakaev in his work defines the concept of compatibility: "Word combination is one of the grammatical features of the language. Within the syntax section, word combination deals with the capacity of individual words and their parts to be combined with other words, types of relationships, as 
well as the word functions when combined with each other. Words in the Kazakh language depending on the capacity to combine with each other are divided into two large groups of nominal and verbal. Forms of word communication are syntactic supports that form the basis for the word combination and are a criterion for the word classification" [9, p.40-41].

In the professor R. Amir's works, much attention is paid to the combination of units of syntactic structures and syntactic meanings: "Syntactic meaning is a meaning that conveys abstract grammatical generalizing relations between words and syntactic units" [10].

As for the study of the valency theory by Kazakhsatni scholars, Y. Mamanov wrote: "in order to combine words with each other, there ought to be a common sense between them" [11]. S. Issaev in his research wrote: "lexical compatibility is distinguished at the semantic level, syntactic compatibility - is at the grammatical level" [12]. M. Orazov, who was specially engaged in research on lexical compatibility of words, wrote: "Although there is mention about the syntactic valency in some works in the Kazakh language, but the logical and semantic valency have not become the study objects" [13]. In Kazakh linguistics one of the first researchers on the issues of compatibility was S. Nurkhanov. In his article he proposes to distinguish the phrase from other word combinations. "The phrase - is a linguistic fact, a pattern/construction, a clause, and word compatibility is a reason, a factor, impulse enabling to come the common names into existence" and gives a definition of the compatibility of words: "Compatibility is a structural property forming a small context (background) for linguistic units (phoneme, morpheme, lexeme)" [14, p.72-73]. According to N. G. Kurmanova: the valency of a verb is its syntactic peculiarity, syntaxeme "verb accumulation". The accumulation of syntactic units near the verb (especially near the verb with a personal ending) is the "translators" of syntactic semantics. In this case, not the lexical constructions composed of lexemes but the syntactic constructions having syntaxeme in its composition are taken as a base" [15, p. 57]. Scientist M. Zholshayeva believes that the valency of adjectives is determined based on contiguity [16]. Professor K. Kuderinova by defining the orthogram of words, which are written together and separately, applies the theory of internal and external valency as a basis [17].

G. Syzdykova, who studied the theory of compatibility in the Kazakh language, in her dissertation on the issues of combining words close in meaning and compatibility in general concludes: "Only words close in meaning can be combined with each other" and explains the compatibility in the language as follows: "Not only words are combined with each other, but also morphemes and phonemes in the word composition are also connected with each other based on the compatibility. The compatibility of lexical units at a particular level occur under the particular laws. For example: Words, morphemes and phonemes in the word composition in a sentence Сырт бітімі бұрындыссынан да жарасымды (Б.Н.) combines with each other under the certain rules. Therefore, the combinable property is distinctive not only to individual words, but also morphemes, sounds that form the basis of the word, i.e. phoneme and phoneme are combined, morpheme and morpheme, some lexemes with others in a strictly selective manner. For example, compatibility at the level of phonemes is determined by the signs of compatibility/incompatibility. Should incompatible phonemes connect, they undergo combinatorial changes. Example: басшы (башшы), сенбі (сембі), он күн (оңгүн) and etc. [18].

3. Results. Phrases and valency (compatibility) are not always equal. For instance, phrases Қыздылт сары орамал (a pink scarf), бойы ұзын қыз (a tall girl) have 2 valency bond (қызғыл сары - 1-valency, қызғыл сары орамал -2-valency; бойы ұзын -1-valency, ұзын қыз -2-valency). In the Kazakh linguistics, compatibility is considered as a part of grammar. And phonetic valency, lexical valency is only just becoming study objects.

Therefore, the laws of lexical compatibility should be taken into account while translating words from other languages. For example, the concept of animate, inanimate nature is translated into the Kazakh language as mірі and өлі табигат. In the Kazakh understanding "өлі" (unalive) is a death (the cessation of life) of the living organism that used to be in constant motion. This means that the phenomenon of inanimate nature, though lifeless, but still has the right to exist. Therefore, the equivalents of the words animate, inanimate nature in the Kazakh language mірі and өлі табигат firmly entered the language as the correct word combination.

In the same way, special attention should be paid to lexical word combinations while translating words that do not have equivalents in other languages. For instance, in Kazakh and Russian languages there are a lot of words that are combined with the word "қара" (black). Kара қ̧аваз - is a death notification of a soldier during the Great Patriotic War. This combination is Kazakh ethnocognitive concept. Although the literal translation is "black letter", but in Russian is given by the word "похоронка" (funeral). Another example: "ķapa қ̧ыlз" is translated not as "black girl", but as "girl with dark skin", "rye bread" is given by the phrase "қара нан", and the phrase "backdoor" (in Russian "черньии ход" - literal translation is "black entrance") in the Kazakh language is "жасырын жол". Thus, the word "қара" is not always translated into 
Russian as "черный" (black); or a combination of кір сабын is translated not as "dirty soap", but as a laundry soap ("шаруашылық сабыны”). Therefore, when combining words, taking the rules of compatibility, semantic compatibility of words into account is always essential.

The rules of morphological compatibility are also important for the compliance with the rules of the Kazakh language. This is especially necessary to take into account when drawing up the phrase with the determinative words in -ған, -ген, -қан, -кен, -гіш, -ғыш, -гі, -ғы, -дік, -дық. For example, сүзеген сиыр (not сүзгіш сиыр), қабаван ит (not қапқыши ит), түнгі жаңбыр (not түндік жаңһбыр), тарихи құбыльыс (not тарихтық құбыльсс), айелдік мейірім (not дйели мейірім). However, there are ways of morphological compatibility that do not obey the rules. For example, күзгі жапырақ (an autumn leaf), күздік киім (autumn clothes); өлшегіш циркуль (a pair of dividers); қысымөлшеуіш құрал (a pressuremeasuring instrument); астарлы ақиқат (a genuine truth), астарлық мата (a cloth padding). As we can see from the examples, suffixes synonyms do not always generate words-synonyms, but serve to distinguish the meaning of words. For example, the suffix $-2 i$ form the words denoting natural phenomena, and the suffix -дік in the word күздік denotes time of the year, season. Suffixes -zim and -yim in the words of өлиегіш аnd өлиеуіш serve to distinguish the meaning of words. -гіш indicates quality, -уіш calls the word. Suffixes -льl, -льlқ in the words астарлы, астарлық are used to differentiate the meaning and added not to all words, but only selectively. Thus, suffixes are added to words under the semantic and syntagmatic rules. And possible compatibility of suffixes is taken into consideration.

4. Discussion. In the Kazakh language, writing words that are written together and separately cause difficulties, as the language is always in development. The modern Kazakh language is undergoing serious dynamic changes. The development of technology, production, industry, business enabled to loan a large number of foreign words into the Kazakh language, in a consequence of which the language has a lot of new names formed by a combination of words, so there has been observed that deviances from language spelling norms are everywhere, since the rules remain the same, and new rules are being developed slowly. Entry of new words into the language requires new rules. And we believe that it is necessary to have spelling rules to write the words together and separately. Since the new words are mainly formed by a combination of two or three components of language units. For example, the name of the cobbler's tool - ақ̧сақтемір (craftsman's tool is made of good quality steel with a sharp point and two handles) is formed by the internal valency of the words as ақсақ and темір. And has nothing to do with the words бiз we (an awl), жin (a thread), қайшь (scissors), пышақ (a knife) that are named on similarity of appearance. The semantic field of the word aқс⿰ақ has no relation to the trade of a shoemaker. However, it has not served as an obstacle and a word as a name is firmly established in the language and written together. And the name of the famous historical figure "Ақсақ Темір" (Aksak Temir) is written separately. Thus, we believe that in order to accurately determine the name of a combination, it is necessary to clarify the crucial points of the compatibility rules.

5. Conclusions. Compatibility rules should be considered at all levels of the language (phonetics, lexis, grammar, spelling, speech culture). Only this will facilitate the harmonisation of compatibility rules in the Kazakh language.

\section{REFERENCES}

1. Domestic Kuznetsov A.M. Katsnelson Solomonovy Davidovich. Linguist of the 20th century //. Part $1 /$ M.: INION of RAS, 2002. 606 pages.

2. Helbig G. Parts of speech and problem of valency in modern German / Educational helbig. M. 1978. - 259 pages.

3. Gak V.G. Valentnost's hook / / Linguistic encyclopaedic dictionary - M.: Soviet encyclopedia, 1990. 689 pages.

4. Kotelova N. Z. Value of word and his compatibility L.: Nayka, 1975. - 73 pages.

5. Vlavatskaya M.V. Combinatorics lexicography (to statement of a problem) // News of the International academy of sciences of higher school / / M. 2006. No 1 (35). Page 167176.

6. Boguslavsky I. M. Sphere of action of lexical units. M.: About languages of culture, 1996. 464 with.

7. Helbig G. Wörterbuch zur Valenz und Distribution deutscher Verben. Leipzig, 1975. 458 S.

8. Sommerfeldt K.-E., Schreiber H. Wörterbuch zur Valenz und Distribution deutscher Adjektive. Leipzig, 1977.

9. Balakayev M. Kazakh language. And, 1987. - 272p.

10. Amir R., Amirova Syntax of simple sentence: Textbook. - Almaty: On Kazakh the university, 2003. - 199 p.

11. Mamanov. Problems of Kazakh linguistics. Almaty: Arys, 2007.

12. Isaev S. Ideas about Kazakh language. - Almaty, 1997.

13. Orazov M. Semantics of Kazakh language. - Almaty 1991.-213p

14. Nurhanov S. Valency and types of compatibility. - Almaty 1965. - No12. 71-74p.

15. Kurmanova N.Zh. System-structural character word-combination of Kazakh language Journal announcer KazNPU Philology series, - Almaty. 2001. - 70p.

16. Zholshaeva M. Ability of compatibility of adjectives is in Kazakh - Almaty, 2001. - 24 b.

17. Kuderinova K. Orthography of continuous and not continuous words - Almaty, 2005.

18. Syzdykova G. O. Semantic valency is in Kazakh language. - Astana, 2010. - 27 p. 